\title{
PENGARUH PEMBELAJARAN KEWIRAUSAHAAN DAN MOTIVASI BERWIRAUSAHA TERHADAP MINAT BERWIRAUSAHA MAHASISWA PRODI MANAJEMEN STIE PEMBANGUNAN TANJUNGPINANG
}

\author{
Armansyah $^{1}$, Yuritanto ${ }^{2}$ \\ ${ }^{1,2}$ Program Studi Manajemen, STIE Pembangunan, Tanjungpinang, Indonesia \\ Email : armansyah@gmail.com, yurianto@gmail.com
}

\begin{abstract}
Abstrak
Tujuan Penelitian ini adalah untuk mengetahui pengaruh Pembelajaran Kewirausahaan dan Motivasi Berwirausaha terhadap Minat Berwirausaha mahasiswa prodi Manajemen STIE Pembangunan Tanjungpinang Angkatan tahun 2020-2021. Penelitian ini menggunakan metode penelitian kuantitatif. Teknik pengumpulan data Kuisioner, yang kemudian selanjutnya dilakukan analisis data Uji Regresi Linier Berganda, kemudian dilakukan Uji F dan Uji T. Hasil penelitian menunjukkan bahwa (1) variabel Pembelajaran Kewirausahaan terhadap Minat Berwirausaha mahasiswa dinyatakan berpengaruh signifikan yang dibuktikan dari uji t yaitu Nilai $\mathrm{T}_{\text {hitung }}>\mathrm{T}_{\text {tabel }}(4.000>1.99045)$ dan nilai signifikan $\mathrm{t}$ kurang dari 5\% $(0,000)$, (2) variable Motivasi Berwirausaha terhadap Minat Berwirausaha dinyatakan berpengaruh signifikan yang dibuktikan dari uji t yaitu Nilai $T_{\text {hitung }}>\mathrm{T}_{\text {tabel }}(4.000>1.99045)$ dan nilai signifikan t kurang dari 5\% (0,000), (3) variabel Pembelajaran Kewirausahaan dan Motivasi Berwirausaha terhadap Minat Berwirausaha mahasiswa dinyatakan berpengaruh signifikan yang dibuktikan dari hasil uji $\mathrm{F}$ yaitu hasil hitung dihasilkan Nilai $\mathrm{F}_{\text {hitung }}<\mathrm{F}_{\text {tabel }}(3,11<51,580$ ) dan nilai signifikansi $(0,000<0,05)$.
\end{abstract}

Kata kunci: Pembelajaran Kewirausahaan, Motivasi Berwirausaha, Minat Berwirausaha

\section{THE EFFECT OF FRONT ENTERPRISE LEARNING AND ENTERPRISE MOTIVATION ON ENTERPRISE INTEREST OF STUDENTS OF MANAGEMENT STIE DEVELOPMENT OF TANJUNGPINANG}

\begin{abstract}
The purpose of this study was to determine the effect of Entrepreneurship Learning and Entrepreneurial Motivation on Entrepreneurial Interest in STIE Pembangunan Tanjungpinang Management Study Program students, batch 2020-2021. This research uses quantitative research methods. The data collection technique was questionnaire, which was then analyzed using the Multiple Linear Regression Test data, then the F test and the T test were carried out. The results showed that (1) the entrepreneurial learning variable on students' entrepreneurial interest was declared to have a significant effect as evidenced by the t test, namely the value of $t$ count $>T$ table (4,000> 1,99045) and a significant value of $t$ less than 5\% (0,000), (2) the entrepreneurial motivation variable on entrepreneurial interest is stated to have a significant effect as evidenced by the $t$ test, namely the value of $t>t$ table $(4,000>1,99045)$ and the significant value of $t$ is less. of 5\% (0,000), (3) the variables of Entrepreneurship Learning and Entrepreneurial Motivation on Student Entrepreneurial Interest are stated to have a significant effect as evidenced by the results of the $F$ test, namely the results of the calculation result in Fcount value $<$ Ftable $(3.11<51.580)$ and a significance value $(0.000<0.05)$.
\end{abstract}

Keywords: Learning Entrepreneurship, Entrepreneurial Motivation, Entrepreneurial Interest 


\section{PENDAHULUAN}

Krisis ekonomi yang melanda Indonesia tidak saja melumpuhkan dunia usaha, tetapi juga menggoyahkan sendi-sendi kesejahteraan masyarakat luas. Dunia kerja makin menjadi sempit, sementara masyarakat yang membutuhkan kerja meningkat. Adanya pengangguran dalam anggota keluarga merupakan masalah. Secara luas, ini juga berarti pengangguran yang disebabkan ketiadaan lapangan pekerjaan akhirnya menjadi tanggungan masyarakat juga. Pengangguran ini bukanlah hasil sebuah pilihan untuk tidak bekerja, tetapi akibat dari semakin sulitnya mendapatkan pekerjaan, terutama di kota-kota besar. Masalah-masalah di atas sebenarnya dapat diperkecil dengan cara berwirausaha dan menjadi pengusaha merupakan alternatif pilihan yang tepat untuk mengatasi pengangguran. Seperti yang dikemukakan (Alma, 2016) dalam bukunya, bahwa semakin maju suatu negara semakin banyak orang terdidik, dan semakin dirasakan pentingnya dunia wirausaha.

Wirausaha merupakan salah satu pendukung yang menentukan maju mundurnya perekonomian, karena bidang wirausaha mempunyai kebebasan untuk berkarya dan mandiri. Jika seseorang mempunyai kemauan dan keinginan serta siap untuk berwirausaha, berarti seseorang itu mampu menciptakan lapangan pekerjaan sendiri, dan tidak perlu mengandalkan orang lain maupun perusahaan lain untuk mendapatkan pekerjaan lagi.Pemerintah telah melakukan berbagi upaya untuk menghapuskan atau menekan kemiskinan, namun hal itu belumlah menunjukkan hasil seperti yang diharapkan. Upaya pemberdayaan masyarakat yang dilakukan oleh Kementerian Pendidikan dan Kebudaayaan adalah melalui pembenahan kurikulum pendidikan, dari mulai tingkat menengah sampai perguruan tinggi. Antara lain adalah dengan memasukkan/menambahkan mata pelajaran/mata kuliah kewirausahaan, yang dimaksudkan untuk menanamkan jiwa kewirausahaan pada generasi muda, perguruan tinggi sebagai jenjang pendidikan formal paling tinggi, diharapkan dapat mencetak generasi muda yang mandiri dan dapat menggugah atau membangkitkan kesadaran mahasiswa untuk menjadi orang yang bisa menciptakan pekerjaan (job creator) bukan orang yang mencari pekerjaan (job seeker).Peranan perguruan tinggi dalam hal ini adalah mempersiapkan dan memberikan pendidikan kepada anak muda supaya memiliki daya saing dan tidak tertinggal oleh yang lain. Selain itu perguruan tinggi harus bisa menjawab tantangan yang saat ini dihadapi oleh bangsa ini seperti lemahnya kemampuan berinovasi masyarakat Indonesia, kesiapan teknologi, riset pendidikan tinggi dan infrastruktur. Pernyataan di atas memberikan perhatian lebih kepada anak muda, agar memiliki skill dalam berwirausaha, tujuannya supaya bisa membangun lapangan pekerjaan. Dalam berwirausaha ada beberapa hal yang perlu menjadi modal selain materi modal yang bersifat non materi perlu dimiliki oleh seseorang yang mau memilih untuk berwirausaha. Salah satu modal selain materi yang harus dimiliki untuk berwirausaha adalah minat berwirausaha, minat berwirausaha menurut (Fuadi 2009) adalah keinginan, ketertarikan, serta kesedian untuk bekerja keras atau berkemauan keras untuk berusaha secara maksimal untuk memenuhi kebutuhan hidupnya tanpa merasa takut dengan resiko yang terjadi serta berkemauan keras untuk belajar dari kegagalan. Sedangkan menurut (Evaliana 2015), minat berwirausaha adalah rasa tertarik untuk menciptakan suatu usaha dengan kemampuan yang dimiliki dan berani mengambil resiko. Dapat disimpulkan bahwa minat berwirausaha adalah 
keinginan yang ada di dalam diri seseorang untuk bekerja keras untuk menciptakan suatu usaha dengan kemampuan yang dimiliki sehingga berani mengambil resiko.Berjiwa berani mengambil resiko artinya bermental mandiri dan berani memulai usaha, tanpa diliputi rasa takut atau cemas sekalipun dalam kondisi tidak pasti. Pendapat di atas menjelaskan bahwa perlu bersikap aktif, serta membangkitkan minat berwirausaha, agar kehidupan tidak bergantung lagi dengan orang lain, karena dengan berwirausaha seseorang bisa mengambil tanggung jawab atas hidupnya sendiri dan tidak bergantung lagi pada orang lain ataupun oleh keadaan yang sedang terjadi. Salah satu pendorong pertumbuhan kewirausahaan di suatu negara terletak pada peranan universitas atau perguruan tinggi melalui penyelenggaraan pendidikan kewirausahaan. Pihak universitas atau perguruan tinggi bertanggung jawab dalam mendidik dan memberikan kemampuan wirausaha kepada para lulusannya dan memberikan motivasi untuk berani memilih berwirausaha sebagai karir mereka. Pihak perguruan tinggi perlu menerapkan pola pembelajaran yang konkrit berdasarkan masukan yang empiris untuk membekali mahasiswa dengan pengetahuan yang bermakna agar dapat mendorong semangat mahasiswa untuk berwirausaha.Pernyataan di atas menyatakan bahwa universitas atau perguruan tinggi memiliki peranan dalam pertumbuhan jumlah wirausahawan disuatu negara, maka perlu adanya pendidikan kewirausahaan, adanya suatu pola pendidikan yang membuat mahasiswa memiliki mindset sikap dan perilaku untuk mau berwirausaha sehingga kegiatan berwirausaha dapat berkembang serta diharapkan berdampak pada kegiatan ekonomi, sosial dan budaya. Perlunya peranan dari universitas atau perguruan tinggi untuk menumbuhkan minat berwirausaha serta dapat membentuk mindset agar mau berwirausaha, salah satu perguruan tinggi yang terletak di Kota Tanjungpinang Provinsi Kepulauan Riau, STIE Pembangunan Tanjungpinang, sebagai salah satu perguruan tinggi swasta, juga memiliki serta mempunyai kewajiban untuk mendukung program yang telah dilakukan adalah merubah visi/misi menjadi menumbuhkan jiwa kewirausahaan dan kurikulum yang semula matakuliah kewirausahaan ditempuh dalam 3 sks dalam satu kali pertemuan/tatap muka maka sekarang menjadi 6 sks yang terdiri dari 2 semester. Pemberian matakuliah kewirausahaan bertujuan agar mahasiswa memiliki jiwa, sifat dan sikap wirausaha, serta menumbuhkan minat dan bakat mereka yang langsung dipraktekkan dalam bentuk adanya penilaian dari dosen dalam bentuk pameran yang dilakukan diakhir pertemuan perkuliahan. Dengan adanya pemahaman tentang kewirausahaan serta dimilikinya jiwa dan karakteristik wirausaha, diharapkan mereka akan dapat menciptakan lapangan pekerjaan.

\section{Rumusan Masalah}

Berdasarkan latar belakang maka dibuatlah rumusan masalah sebagai berikut:

1. Apakah ada pengaruh pembelajaran kewirausahaan terhadap minat berwirausaha mahasiswa prodi Manajemen STIE Pembangunan Tanjungpinang Angkatan tahun 2020-2021?

2. Apakah ada pengaruh motivasi berwirausaha terhadap minat berwirausaha mahasiswa prodi Manajemen STIE Pembangunan Tanjungpinang Angkatan tahun 2020-2021?

3. Apakah ada pengaruh pembelajaran kewirausahaan dan motivasi berwirausaha terhadap minat berwirausaha mahasiswa prodi Manajemen STIE Pembangunan Tanjungpinang Angkatan tahun 2020-2021? 


\section{Tujuan Penelitian}

Penelitian ini bertujuan untuk Mengetahui pengaruh pembelajaran kewirausahaan terhadap minat berwirausaha mahasiswa prodi Manajemen STIE Pembangunan Tanjungpinang Angkatan tahun 2020-2021.

1. Mengetahui pengaruh motivasi berwirausaha terhadap minat berwirausaha mahasiswa prodi Manajemen STIE Pembangunan Tanjungpinang Angkatan tahun 2020-2021.

2. Mengetahui pengaruh pembelajaran kewirausahaan dan motivasi berwirausaha terhadap minat berwirausaha mahasiswa prodi Manajemen STIE Pembangunan Tanjungpinang Angkatan tahun 2020-2021.

3. Pemilihan kajian ini berdasarkan ketertarikan peneliti terhadap minat mahasiswa Prodi Manajemen STIE Pembangunan Tanjungpinang Angkatan 2020-2021 untuk berwirausaha setelah mengikuti perkuliahan mata kuliah kewirausahaan atau minat berwirausaha dikarenakan factor lainnya

\section{KAJIAN TEORI}

\section{Kinerja}

Manajemen sumber daya manusia sangat erat kaitannya dengan keunggulan organisasi. Keunggulan organisasi juga tidak bisa dipisahkan dari kinerja sunber daya manusia yang ada dalam suatu organisasi. Wether dan Davis dalam Isyandi (2018) menyatakan bahwa kinerja dapat digambarkan sebagai apa yang dapat dicapai atas prestasi yang dilihat, kemampuan kerja (alat), bekerja berkemampuan dan bertenanga. Sedarmayanti (2011) mengemukakan bahwa kinerja merupakan terjemahan dari performance yang berarti hasil kerja seorang pekerja, sebuah proses manajemen atau suatu organisasi secara keseluruhan, dimana hasil kerja tersebut harus dapat ditunjukkan buktinya secara konkrit dan dapat diukur (dibandingkan dengan standar yang telah ditentukan).

\section{Motivasi}

Manajemen sumber daya manusia tidak terlepas dari usaha dalam memberikan dorongan dan menggerakkan orang-orang agar bersedia bekerja semaksimal mungkin demi tercapainya tujuan sehingga perlu diusahakan adanya komunikasi dan peran serta dari semua pihak yang bersangkutan. Menurut Hasibuan dalam Isyandi (2017) Motivasi adalah mempersoalkan bagaimana cara mengarahkan daya dan potensi bawahan, agar mau bekerjasama secara produktif berhasil mencapai dan mewujudkan tuhuan yang telah ditentukan. Motivasi sangat penting karena motivasi adalaha hal yang menyebabkan, menyalurkan, dan mendukung perilaku manusia supaya mau bekerja giat dan antusias mencapai hasil yang optimal. Perusahaan bukan saja mengharapkan pegawai mampu, cakap, dan terampil tetapi juga mau bekerja giat dan berkeinginan mencapai hasil maksimal.

Motivasi adalah suatu faktor yag mendorong seseorang untuk melakukan suatu aktivitas tertentu (Sutrisno, 2011). Motivasi menjadi salah satu pondasi penting bagi tumbuhnya kinerja pegawai dalam sebuah organisasi. Bagaimanapun setiap pegawai akan terpacu untuk bekerja 
lebih keras jika memiliki dan atau terdapat motivasi di dalamnya. Bahkan kepuasan dari hasil pekerjaan dan bagi pegawai bersangkutan sangat tergantung dari peran pimpinan menumbuhkan motivasi.

Robbins dan Counter (Suwatno dan Donni, 2013) mengemukakan motivasi kerja sebagai kesediaan untuk melaksanakan upaya tinggi untuk memenuhio kebutuhan individual tertentu. Dari beberapa definisi di atas, dapat dismpulkan bahwa organisasi hanya akan berhasil mencapai tujuan dan berbagai sasarannya, apabila semua komponen organisasi berupaya menampilkan kinerja atau memiliki motivasi yang tinggi secara optimal.

\section{Kompetensi}

Kompetensi dikatakan sebagai salah satu faktor yang mempengaruhi kinerja. Kompetensi adalah karakteristik dasar yang dapat di hubungkan dengan peningkatan kinerja individu atau tim. Menurut Edison, dkk (2017) Kompetensi adalah kemampuan individu untuk melaksanakan suatu pekerjaan dengan benar dan memiliki keunggulan yang didasarkan pada hal-hal yang menyangkut pengetahuan, keahlian, dan sikap. Menurut George Klemp (dalam Edison, dkk, (2017) Kompetensi adalah karakteristik yang mendasari seseorang menghasilkan pekerjaan yang efektif dan atau kinerja yang unggul. Menurut Spencer and Spencer dalam Edison, dkk (2017) menambahkan bahwa " a competency is an underying characteristic of individual that is causally related to criterion referenced effective and or superior peformance in a job or situation". Artinya bahwa karakteristik yang mendasari individu yang berkaitan dengan hubungan kausal atau sebab akibat pelaksanaan yang efektif dan atau unggul dalam pekerjaan atau keadaan)

Sriwidodo dan Haryanto (2010) mengemukakan pendapatnya bahwa kinerja dan keefektifan pegawai dalam melaksanakan tugas sangat ditentukan oleh kompetensi yang disyaratkan oleh bidang pekerjaan. Kompetensi seseorang menjadi ciri dasar individu dikaitkan dengan standar kriteria kinerja yang efektif dan superior. Berkaitan dengan ungkapan di atas spencer dan spencer dalam Abdussamad (2011) membagi kompetensi dalam dua tingkatan yakni ada yang tampak dan yang tidak tampak, Spencer dan spencer mengilustrasikan seperti gunung es di mana ada yang tampak di permukaan, adapula yang tidak terlihat di permukaan.

Kompetensi yang tampak di pemukaan adalah Pengetahuan (Knowledge) dan Keterampilan (Skill), kompetensi yang tidak tampak di permukaan adalah Nilai-nilai(Srole), konsep diri (self image), karakteristik personal (traits), dan motif (motives). Kompetensi di temukan pada orang-orang yang di klasifikasikan sebagai berkinerja unggul atau efektif. Dari pengertian di atas dapat ditarik tegaskan bahwa kompetensi yaitu kemampuan seseorang berkinerja untuk melaksanakan pekerjaan dengan sukses serta menghasilkan prestasi kerja, dan kesuksesan suatu organisasi tergantung pada kombinasi kompetensi kepemimpinan yang efektif dan kompetensi tenaga kerjanya.

\section{Lingkungan Kerja}

Lingkungan kerja mempunyai pengaruh yang sangat besar terhadap pegawai dalam melaksanakan operasi perusahaan. Kondisi lingkungan kerja yang baik dan memadai, akan menunjang para pegawai menjadi senang dengan tempat kerjanya. Dengan adanya perasaan 
senang terhadap tempat kerjanya maka akan menimbulkan perasaan puas pada diri pegawai dan akan menimbulkan semangat kerja yang lebih baik sehingga tujuan-tujuan organisasi akan tercapai pula dengan baik.

Lingkungan kerja adalah tempat dimana pegawai melakukan aktivitas setiap harinya. Lingkungan kerja yang kondusif memberikan rasa aman dan memungkinkan pegawai untuk dapat bekerja optimal. Lingkungan kerja dapat mempengaruhi emosi pegawai. Jika pegawai menyenangi lingkungan kerja dimana dia bekerja, maka pegawai tersebut akan betah di tempat kerjanya, melakukan aktivitas sehingga waktu kerja dipergunakan secara efektif. Lingkungan kerja itu mencakup hubungan kerja yang terbentuk antara sesama pegawai dan hubungan kerja antara bawahan dan atasan serta lingkungan fisik tempat pegawai bekerja.

\section{METODE PENELITIAN}

\section{Desain Penelitian}

Desain yang dipergunakan dalam ini penelitian kuantitatif. Dalam metoda ini teori ilmiah yang telah diterima kebenarannya dijadikan acuan dalam mencari kebenaran selanjutnya. Penelitian kuantitatif merupakan suatu proses menemukan pengetahuan yang menggunakan data berupa angka sebagai alat menganalisis keterangan mengenai apa yang ingin diketahui Penelitian ini akan dilakukan mulai bulan Mei 2019 sampai dengan bulan Juli 2020. Untuk mendapatkan data yang diperlukan dalam penulisan tesis ini, penulis mengadakan penelitian pada Dinas Tanaman Pangan Hortikultura dan Perkebunan Provinsi Riau di Kota Pekanbaru.

\section{Populasi dan Sampel}

Populasi adalah wilayah generalisasi yang terdiri atas objek atau subjek yang mempunyai kualitas dan karakteristik tertentu yang ditetapkan oleh peneliti untuk dipelajari dan kemudian ditarik kesimpulan.Populasi dari penelitian ini adalah seluruh karyawan Dinas Tanaman Pangan Hortikultura dan Perkebunan Pekanbaru yang berjumlah 385 orang. Apabila subjek penelitian lebih dari 100 orang, maka penelitian menggunakan rumus Slovin orang dapat diambil derajat ketidakpastian antara 5-10\% (Arikunto, 2011). Oleh karna itu yang dijadikan sampel adalah sebanyak 196 orang pegawai. Dengan teknik pengambilan sampel stratified sampling dan purposive sampling, dimana kita yang menentukan sendiri sampel yang di ambil, dengan rumus Slovin :

$$
\begin{aligned}
& \mathbf{N}=\frac{\mathbf{N}}{\mathbf{1 + n}(\mathbf{e})^{2}}=\frac{\mathbf{3 3 5}}{\mathbf{1 + 3 3 5 ( \mathbf { 0 , 0 5 } ) ^ { 2 }}=\mathbf{1 7 0}} \\
& \text { Keterangan : } \\
& \mathrm{N} \quad \text { : Populasi } \\
& \mathrm{n} \quad \text { : Ukuran Sampel } \\
& \mathrm{E} \quad \text { :Tingkat kesalahan pengambilan sampel 5\% }(0,05)
\end{aligned}
$$

Sampel berdasarkan tingkat golongan pegawai mulai dari I sampai IV. 
Tabel 1. Sampel

\begin{tabular}{llll}
\hline No. & Golongan & Jumlah & Sampel \\
\hline $\mathbf{1 .}$ & I & 4 & 2 \\
\hline $\mathbf{2 .}$ & II & 78 & 45 \\
\hline $\mathbf{3}$ & III & 212 & 102 \\
\hline $\mathbf{4}$ & IV & 41 & 25 \\
\hline & Jumlah & 335 Orang & 170 Orang
\end{tabular}

Sumber : Dinas Tanaman Pangan, Hortikultura dan Perkebunan Provinsi Riau (2018)

Stratified sampling merupakan cara penarikan sampel untuk populasi yang memiliki karakteristik heterogen atau karakteristik yang dimiliki populasi bervariasi dengan tujuan agar setiap kelompok variasi mendapat kesempatan untuk diteliti. Jadi sampel penelitian telah terdiri dan mewakili dari masing-masing tingkatan kelompok yang ada.

\section{Teknik Pengumpulan Data}

Teknik pengupulan data yang dipergunakan dalam penelitian ini adalah :

- Wawancara yaitu cara pengumpulan data yang penulis lakukan dengan melakukan interview pada tempat penelitian.

- Kuesioner yaitu pengumpulan data dengan cara menyusun pertanyaan yang diajukan kepada karyawan.

\section{Analisis Jalur (Path Analysis)}

Analisis jalur digunakan untuk menguji pengaruh secara parsial (individual) dan simultan (keseluruhan) dari variabel bebas (independent) terhadap variabel terikat (dependent). Melalui analisis jalur ini akan ditemukan jalur mana yang paling tepat dan singkat suatu variabel independen menuju variabel dependent yang terakhir dan juga menganalisis hubungan antarvariabel dengan tujuan untuk mengetahui pengaruh langsung maupun tidak langsung seperangkat variabel bebas terhadap variabel terikat yang diolah dengan menggunakan sofware SPSS (stastistical package for sosial scienci) versi 21. Analisis jalur adalah bagian dari model regresi yang dapat digunakan untuk menganalisis hubungan sebab akibat antar satu variabel dengan variabel lainnya. Analisis jalur digunakan dengan menggunakan korelasi, regresi dan jalur sehingga dapat diketahui untuk sampai pada variabel dependen terakhir, harus lewat jalur langsung atau melalui variabel intervening (Sugiyono, 2013:70).

Berdasarkan hipotesis yang diajukan. Maka model analisa jalur dalam penelitian ini dengan rumus ;

$$
\begin{aligned}
& Y_{1}=\rho 1 X_{1}+\rho_{2} X_{2}+e_{1} \ldots \ldots \ldots . . .(1) \\
& Y_{2}=\rho X_{1} Z X_{1}+\rho x_{2} Z X_{2}+\rho Z Y_{1}+e_{2} \ldots(2)
\end{aligned}
$$

Keterangan:

$\mathrm{Y}_{1}=$ Variabel Motivasi

$\mathrm{Y}_{2}=$ Variabel Kinerja

$\mathrm{a}=$ konstanta

$\mathrm{X}_{1}=$ Variabel Kompetensi

$\mathrm{X}_{2}=$ Variabel Lingkungan kerja 
$\rho 1=$ Koefisien jalur kompetensi terhadap motivasi

$\rho_{2}=$ Koefisien jalur lingkungan kerja terhadap motivasi

$\rho y_{1}=$ Koefisien jalur motivasi terhadap kinerja

$\rho \mathrm{x}_{1} \mathrm{Y}_{2}=$ Koefisien jalur kompetensi terhadap kinerja

$\rho \mathrm{x}_{2} \mathrm{Y}_{2}=$ Koefisien jalur lingkungan kerja terhadap kinerja

e = Kesalahan

Untuk menguji hipotesis parsial maka dapat dilakukan pengujian yang digunakan adalah uji t dengan rumus sebagai berikut :

$$
\mathrm{t}=\sqrt{\frac{n-(k+1)}{1-r^{2}}}
$$

Dimana :

$\mathrm{n}$ = Jumlah sampel

$r=$ Nilai Korelasi parsial

$\mathrm{k}=$ Jumlah variabel indepeden

Pengujian uji t telah dilakukan maka hasil pengujian tersebut $t$ hitung dibandingkan $t$ tabel dengan ketentuan sebagai berikut :

a. Jika $\mathrm{t}_{\text {hitung }}>\mathrm{t}_{\text {tabel }}$ maka $\mathrm{H}_{0}$ ditolak.

b. Jika $t_{\text {hitung }}<\mathrm{t}_{\text {tabel }}$ maka $\mathrm{H}_{0}$ diterima.

\section{HASIL DAN PEMBAHASAN}

Berdasarkan hasil pengolahan data regresi pada hasil pengolahan diatas, didapatkan hasil pengaruh langsung yang didapatkan melalui proses pengolahan data. Pada analisis jalur, terdapat 2 (dua) jenis pengaruh yang didapat, yaitu pengaruh langsung dan tidak langsung yang kemudian ditotal menjadi pengaruh total keseluruhan variabel terhadap Kinerja Pegawai yang dihasilkan.

\section{Pengaruh Langsung}

Hasil pengaruh langsung penelitian dapat dilihat dari pengujian secara parsial yang dilakukan di tiap struktural penelitian. Pengaruh langsung tiap variabel bebas dihitung dengan rumus:

$$
\text { Pengaruh Langsung Variabel }=\left(\rho \mathrm{x}_{\mathrm{iyi}}\right)^{2}
$$

Hasil dari perhitungan tersebut, didapatkan hasil pengaruh langsung sebagai berikut:

Tabel 2. Pengaruh Langsung

\begin{tabular}{lrr}
\hline \multicolumn{1}{c}{ Variabel } & \multicolumn{1}{c}{ Motivasi } & \multicolumn{1}{c}{ Kinerja } \\
\hline Kompetensi & 0.155 & 0.173 \\
\hline Lingkungan & 0.036 & 0.139 \\
\hline Motivasi & & 0.118 \\
\hline
\end{tabular}




\section{Pengaruh Tidak Langsung}

Hasil pengaruh langsung penelitian dapat dilihat dari pengujian secara parsial yang dilakukan di tiap struktural penelitian. Pengaruh tidak langsung tiap variabel bebas dihitung dengan rumus:

$$
\text { Pengaruh Tidak Langsung Variabel }=\mathrm{ry}_{1 \mathrm{Xi}} \mathrm{x} \rho_{\mathrm{y}_{2}{ }_{1} \mathrm{x}} \rho_{\mathrm{y}_{2} \mathrm{Xi}}
$$

Hasil pengolahan rumus tersebut didapatkan hasil pengaruh tidak langsung penelitian adalah sebagai berikut:

Tabel 3. Pengaruh Tidak Langsung

\begin{tabular}{ccccc}
\hline Keterangan & $\mathbf{r}_{\mathbf{y 1 x i}}$ & $\boldsymbol{\rho Y}_{2 Y 1}$ & $\boldsymbol{\rho Y 2 X i}$ & Total \\
& & & & \\
\hline $\mathbf{X}_{\mathbf{1}}$ & 0.480 & 0.344 & 0.416 & 0.069 \\
\hline $\mathbf{X}_{\mathbf{2}}$ & 0.367 & 0.344 & 0.373 & 0.047 \\
\hline
\end{tabular}

\section{Pengaruh Total}

Hasil pengaruh langsung penelitian dapat dilihat dari total pengaruh langsung dijumlah kan dengan pengaruh tidak langsung yang dilakukan di tiap struktural penelitian. Berikut ini merupakan perhitungan pengaruh total penelitian.

\begin{tabular}{cccc} 
& \multicolumn{3}{c}{ Tabel 4. Pengaruh Total } \\
\hline Variabel & $\begin{array}{c}\text { Pengaruh } \\
\text { Langsung }\end{array}$ & $\begin{array}{c}\text { Pengaruh } \\
\text { Tidak } \\
\text { Langsung }\end{array}$ & Total \\
\hline Kompetensi & 0.173 & 0.069 & 0.242 \\
\hline Lingkungan & 0.139 & 0.047 & 0.186 \\
\hline Motivasi & 0.118 & & 0.118 \\
\hline \multicolumn{3}{c}{ Total Pengaruh } & $\mathbf{0 . 5 4 6}$ \\
\hline
\end{tabular}

Berdasarkan perhitungan yang telah dilakukan didapatkan pengaruh total kompetensi, lingkungan kerja, dan motivasi terhadap kinerja didapatkan total pengaruh sebesar 0,546, atau memiliki persentase pengaruh sebesar 54,6\%.

\section{Diagram Jalur Penelitian}

Berdasarkan hasil pada tabel 2 dan 4 maka didapatkan diagram jalur penelitian adalah sebagai berikut:

\section{Gambar 1 Diagram Jalur}

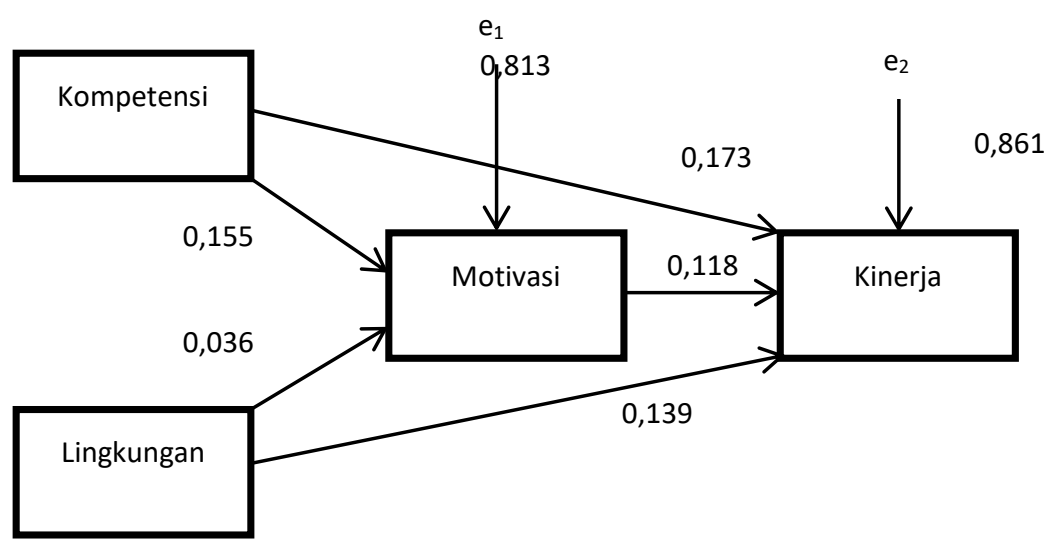




\section{PEMBAHASAN}

Penelitian ini berjudul Pengaruh Kompetensi dan Lingkungan Kerja Terhadap Motivasi Serta Kinerja Pegawai Pada Dinas Tanaman Pangan, Holtikultura dan Perkebunan Provinsi Riau. Tujuan penelitian ini adalah untuk mengetahui pengaruh kompetensi dan lingkungan kerja terhadap motivasi serta kinerja pegawai yang mampu memberikan manfaat bagi instansi terkait serta keilmuan. Sampel penelitian ini adalah 170 pegawai dengan teknik pengambilan sampel menggunakan rumus Slovin yang dikombinasikan dengan Stratified sampling sehingga setiap golongan pegawai mendapatkan peluang yang sama untuk dijadikan penelitian. Teknik analisis data yang digunakan adalah analisis jalur.

\section{Pengaruh Motivasi Terhadap Kinerja}

Hasil pada penelitian ini menunjukkan bahwa Motivasi berpengaruh terhadap Kinerja. Motivasi merupakan pendorong agar seseorang melakukan suatu kegiatan untuk mencapai tujuannya. Motivasi dalam mempengaruhi kinerja terlihat dari keterkaitan antara indikator setiap variabel. Dapat dilihat dari indikator dimana jika pegawai mendapatkan penghargaan dan pujian atas prestasinya maka akan berupaya untuk lebih baik dalam pencapaian target dan melaksanakan pekerjaan nya secara efektif.

Jika pegawai memiliki tanggung jawab pekerjaan yang jelas dan pekerjaan yang diberikan tersebut memberikan pembelajaran baru bagi pegawai serta menantang, maka pegawai akan terpacu untuk melakukan proses kerja dengan lebih baik dan memberikan ide serta temuan baru dalam bekerja.

Sehingga, semakin tinggi motivasi pegawai akan semakin meningkatkan kinerja yang dapat dicapai oleh pegawai yang sejalan akan menjadikan semakin tingginya kinerja dari instansi terkait.

Hasil dari penelitian ini juga diperkuat dengan penelitian yang dilakukan oleh Joko Waluyo (2014) dan Anidar KH dan Sri Indarti (2015) yang menemukan bahwasanya motivasi berpengaruh terhadap kinerja.

\section{Pengaruh Kompetensi Terhadap Kinerja}

Hasil pada penelitian ini menunjukkan bahwa kompetensi berpengaruh terhadap kinerja. Kompetensi erat kaitanya dengan kinerja dikarenakan kompetensi merupakan kemampuan dari pegawai dalam melaksanakan seluruh tugas yang diberikan. Semakin tinggi kompetensi pegawai dalam melaksanakan tugas, maka kinerja pegawai akan semakin tinggi.

Semakin baik pengetahuan pegawai mengenai bidang tugasnya dan terknik dalam bekerja maka pegawai akan semakin mampu mencapai target pekerjaan secara tepat waktu bahkan pegawai akan mampu memberikan temuan temuan baru dalam bekerja. Pengetahuan yang baik mengenai peraturan perusahaan akan membuat pegawai lebih baik dalam melaksanakan proses bekerja sesuai dengan SOP yang ada dan pegawai akan menjadi lebih disiplin dalam mengikuti seluruh peraturan perusahaan.

Pengetahuan pegawai mengenai sistem informasi dan alat pendukung pekerjaan juga sangat berperan dalam meningkatkan kinerja. Pegawai yang terampil dalam 
mengoperasikan berbagai sistem dalam pekerjaannya akan mampu untuk menyelesaikan pekerjaan dengan cepat dan cermat.

Hasil dari penelitian ini didukung hasil penelitian yang telah dilakukan sebelumnya oleh Muindi (2015) dan Prabowo (2012), dalam hasil penelitiannya menemukan terdapat pengaruh yang kuat kompetensi terhadap kinerja. Dalam temuan penelitian sebelumnya tersebut ditemukan bahwa kompetensi menjadi andil yang besar dalam meningkatkan kinerja pegawai.

\section{Pengaruh Lingkungan Kerja Terhadap Kinerja}

Hasil pada penelitian ini menunjukkan bahwa Lingkungan kerja berpengaruh terhadap Kinerja. Lingkungan kerja yang dimaksud adalah semua keadaan yang terjadi yang berkaitan dengan hubungan kerja, baik hubungan dengan atasan maupun hubungan sesama rekan kerja, ataupun hubungan dengan bawahan.

Lingkungan kerja yang baik tentunya akan membuat rasa aman dan tentram dalam melaksanakan tugas. Hubungan kerja dan komunikasi yang baik antara sesama pegawai maupun antara atasan dan pegawai akan menghadirkan interaksi yang lebih baik sehingga akan muncul keharmonisan dan kekompakan dalam instansi.

Rasa kekeluargaan antara sesama pegawai maupun antar atasan dan pegawai akan membuat pegawai semakin baik dalam membantu satu sama lain dalam melaksanakan proses bekerja. Hubungan komunikasi yang baik, serta kerjasama yang merupakan faktor tingginya kemampuan instansi dalam melaksanakan aktivitas dinas. Oleh karena itu lingkungan kerja merupakan salah satu variabel yang mempu memberikan dampak yang vital bagi pegawai dalam mencapai kinerja yang baik.

Hasil penelitian ini didukung dengan Penelitian tentang pengaruh lingkungan kerja terhadap kinerja sebelumnya yang telah diteliti oleh Maulabakhsh (2015), yang juga menemukan terdapat pengaruh yang besar dari lingkungan kerja terhadap kinerja.

\section{Pengaruh Kompetensi Terhadap Kinerja Melalui Motivasi}

Hasil pada penelitian ini menunjukkan kompetensi melalui variabel motivasi kerja tidak memiliki pengaruh yang kuat terhadap kinerja. Motivasi tidak dapat memediasi pengaruh kompetensi terhadap kinerja.

Rendahnya pengaruh tidak langsung yang diberikan kompetensi melalui motivasi sebagai pemediasi terhadap kinerja disebabkan oleh pengetahuan pegawai mengenai bidang tugas pekerjaan, kemampuan dalam mengorganisir pekerjaa, serta kreatifitas pegawai tidak secara signifikan meningkatkan penghargaan dan pujian dari atasan sehingga kompetensi tersebut tidak mampu memotivasi pegawai dalam meningkatkan kinerja.

Hal lainnya yang menyebabkan pegawai tidak begitu termotivasi adalah karena terdapatnya bidang pengetahuan pegawai yang tidak sesuai dengan pekerjaan sehingga pegawai merasa pekerjaan nya tidak menarik sehingga tidak cukup untuk memotivasi kearah pencapaian kinerja yang lebih baik.

Hasil ini bertolak belakang dengan hasil penelitian yang telah dilakukan oleh Rahim (2017) dimana dalam temuannya menyatakan motivasi dipengaruhi oleh kompetensi, serta oleh Joko Waluyo (2014) yang menemukan motivasi berpengaruh besar terhadap kinerja. Keterkaitan dari penelitian terdahulu tersebut mencerminkan adanya pengaruh kompetensi 
terhadap kinerja secara tidak langsung, namun penelitian ini tidak menemukan hasil yang sama dengan penelitian yang telah dilakukan sebelumnya.

\section{Pengaruh Lingkungan Kerja Terhadap Kinerja Melalui Motivasi}

Hasil pada penelitian ini menunjukkan lingkungan kerja melalui variabel motivasi kerja tidak memiliki pengaruh terhadap kinerja. Motivasi tidak dapat memediasi pengaruh lingkungan kerja terhadap kinerja.

Rendahnya pengaruh tidak langsung yang diberikan Lingkungan kerja melalui motivasi sebagai pemediasi terhadap kinerja disebabkan oleh hubungan kekeluargaan yang terjalin antar pegawai dan pimpinan tidak mampu meningkatkan secara signifikan komunikasi yang lebih baik mengenai tanggung jawab pekerjaan pegawai dan pencapaian tugasnya. Sehingga lingkungan kerja tidak cukup memotivasi pegawai untuk mencapai kinerja yang maksimal.

Hasil ini bertolak belakang dengan hasil penelitian yang telah dilakukan oleh Saeed (2016) dimana dalam temuannya menyatakan motivasi dipengaruhi oleh lingkungan kerja, serta oleh Joko Waluyo (2014) yang menemukan motivasi berpengaruh besar terhadap kinerja. Keterkaitan dari penelitian terdahulu tersebut mencerminkan adanya pengaruh lingkungan terhadap kinerja secara tidak langsung, namun penelitian ini tidak menemukan hasil yang sama dengan penelitian yang telah dilakukan sebelumnya

\section{KESIMPULAN}

Motivasi berpengaruh terhadap kinerja, yang bermakna semakin tinggi motivasi semakin tinggi pula kinerja pegawai. Semakin baik penghargaan dan pujian yang diberikan terhadap capaian kinerja pegawai, maka semakin baik interaksi antar pegawai dan semakin maksimal dalam pencapaian target perusahaan.Kompetensi berpengaruh terhadap kinerja, yang bermakna semakin tinggi kompetensi pegawai semakin tinggi kinerja pegawai. Semakin baik pengetahuan pegawai mengenai bidang tugasnya, peraturan perusahaan, dan teknik dalam bekerja, maka semakin efektif penggunaan waktu dalam bekerja dan semakin baik dalam pencapaian target perusahaan.Lingkungan berpengaruh terhadap kinerja, yang bermakna semakin tinggi lingkungan kerja semakin tinggi pula kinerja pegawai. Semakin baik komunikasi dan rasa kekeluargaan yang terjalin maka semakin baik kerjasama antar pegawai dan semakin baik pegawai dalam melakukan proses bekerja.Kompetensi tidak berpengaruh secara tidak langsung terhadap kinerja melalui motivasi. Artinya motivasi tidak berperan sebagai mediasi antara kompetensi dengan kinerja. Rendahnya kemampuan pegawai dalam melaksanakan pekerjaan sesuai dengan standar operasional prosedur instansi menjadi masalah yang menyebabkan rendahnya pengaruh tidak langsung yang diberikan kepada kinerja melalui motivasi.Lingkungan kerja tidak berpengaruh secara tidak langsung terhadap kinerja pegawai melalui motivasi. Artinya motivasi tidak berperan sebagai medasi antara lingkungan kerja dan kinerja. Hubungan yang erat antara atasan dan pegawai menjadikan suatu faktor yang mempu meningkatkan level dari lingkungan kerja, akibat buruknya hubungan tersebut menjadikan motivasi kerja karyawan rendah, serta kemudian berdampak buruk bagi kinerja pegawai. 


\section{DAFTAR PUSTAKA}

Abdillah, Willy dan Jogiyanto. 2015. Partial Least Square (PLS) Alternatif Structural Equation Modeling (SEM) dalam Penelitian Bisnis. Ed.1. Yogyakarta: ANDI

Abdul Raziq, Raheela Maulabakhsh. 2015. Impact of Working Environment on Job Satisfaction. Balochistan University of Information Technology. Pakistan.

Agusta, Leonando dan Eddy Madiono Sutanto. 2013. Pengaruh Pelatihan dan Motivasi Kerja terhadap Kinerja Karyawan (studi kasus pada cv. Haragon Surabaya). Universitas Kristen Petra. Surabaya.

Akdon, dan Riduwan, Rumus dan Data dalam Aplikasi Statistika, Bandung: Alfabeta, 2013

Anak Agung Ngurah Bagus Dhermawan. 2012. Pengaruh Motivasi, Lingkungan Kerja, Kompetensi, Dan Kompensasi Terhadap Kepuasan Kerja Dan Kinerja Pegawai Di Lingkungan Kantor Dinas Pekerjaan Umum Provinsi Bali. Jurnal Manajemen, Strategi Bisnis, dan Kewirausahaan Vol. 6, 173 No. 2 Agustus 2012.

B. Isyandi. 2018. Manajemen Sumber Daya Manusia Dalam Perspektif Global. Pekanbaru : UNRI Press.

Dwi Agung Nugroho Arianto. 2013. Pengaruh Kedisiplinan, Lingkungan Kerja Dan Budaya Kerja Terhadap Kinerja Tenaga Pengajar. Jurnal Economia, Volume 9, Nomor 2, Oktober 2013.

Florence Muindi dan Professor Peter K'Obonyo . 2015. Quality of Work Life, Personality, Job Satisfaction, Competence, and Job Performance : A Critical Review of Literature. School of Business, University of Nairobi, Kenya.

Faustyna. 2002. Pengaruh Kompetensi dan Komitmen pada tugas terhadap kinerja karyawan pada Hotel Dharma Deli Medan. Universitas Muhammadiyah Sumatera Utara. Medan.

Hutajulu, Togu Charles Edison. 2012. Pengaruh Kompetensi, Komitmen, dan Perubahan Organisasi Terhadap kinerja Pegawai Negeri Sipil di Lingkungan Sekretariat Daerah kabupaten Tapanuli Tengah. Universitas Terbuka. Jakarta.

Leblebici, Demet. 2012. Impact of Workplace Quality on Employees Productivity : Case Study of a Bank in Turkey. ournal of bussiness, Economics \& Finance ISSN: 2146-7943.

Mangkunegara, Anwar Prabu. 2013, Manajemen Sumber Daya Manusia Perusahaan, Remaja Rosdakarya, Bandung.

M Anang Firmansyah. 2018. Pengaruh Faktor-Faktor Lingkungan Kerja Internal Dan Pekerjaan Terhadap Motivasi Kerja Karyawan Pada Pt. Warnatama Cemerlang Gresik. Balance Vol. XV No. 2 Juli 2018.

Mathis L. Robert dan John H. Jackson. 2012. Manajemen Sumber Daya Manusia. Alih Bahasa. Jakarta : Salemba Empat. Edisi 10.

Meutia, Ika Sari dan Tubagus Ismail. 2014. Pengaruh Kompensasi Dan Kompentesi Dengan Motivasi Sebagai Intervening Dalam Meningkatkan Kinerja. Jurnal Manajemen Volume XX, No. 03, Oktober 2016: 353-369. 
Nitisemito, Alex S. 2010. Manajemen personalia Manajemen Sumber Daya Manusia. Edisi Ketiga. Jakarta : Ghalia Indonesia

Nugroho, Agung. 2012. Pengaruh Motivasi, Lingkungan kerja, Kompetensi dan Kompensasi terhadap kepuasan kerja dan kinerja pegawai dilingkungan kantor Dinas pekerjaan Umum Prov. Bali. Fakultas Ekonomi Universitas Udayana. Bali.

Parveen, Sajida, dkk. 2012. Impact of Office Facilities and Workplace Milieu on Employee's Performance : A Case Study of Sarghoda University. Asian Journal of Empirical Research, 2(4): 96-117. Pakistan.

Pendow, Jessica dan Peggy A Mekel. 2015. Pengaruh Perekrutan, Motivasi, dan Pelatihan Kerja Terhadap Kinerja Karyawan PT. PLN (persero) Wilayah Suluttenggo. Universitas Sam Ratulangi. Manado.

Prabowo, Ady Satya. 2012. Pengaruh kemampuan dan motivasi terhadap kinerja karyawan Akuntansi pada kantor konsultan pajak. STIE Widya Manggala. Semarang.

Putra, Chairuddin Surya, Harlen dan Machasin. 2014. Pengaruh Kepemimpinan, Motivasi Dan Budaya Organisasi Terhadap Kinerja Pegawai Pada Badan Perencanaan Pembangunan Daerah (Bappeda) Kota Dumai. Jurnal Ekonomi Volume 22, Nomor 3 September 2014.

Purwantoro, P., \& Afrizal, A. (2019, August). Evaluation of items on instruments of consumer attitudes, word of mouth, and decisions of private universities. In Journal of Physics: Conference Series (Vol. 1255, No. 1, p. 012092). IOP Publishing.

Rahim. Abdul. 2017. Pengaruh Lingkungan Kerja Dan Kompetensi Terhadap Motivasi Kerja Serta Dampaknya Terhadap Kinerja Pegawai Pada Dinas Pendidikan Kabupaten Tanjung Jabung Timur. J-MAS Vol.2 No.2, Oktober 2017.

Safwan , dkk. 2014. Pengaruh Kompetensi dan Motivasi terhadap Kinerja Pengelolaan Keuangan Daerah pada Pemerintah Daerah Kabupaten Pidie Jaya. Universitas Syiah Kuala. Banda Aceh.

Sanjaya, I Kadek Edy dan Ayu Desi Indrawati. Pengaruh Kompetensi, Kompensasi, dan Lingkungan Kerja terhadap Kinerja Karyawan pada PT. Pande Agung Sedara Dewata. Universitas Udayana (UNUD). Bali.

Setiawan, Budi. 2014. Pengaruh Kompetensi dan Motivasi terhadap Kinerja Pegawai Negeri Sipil di Lingkungan Badan Penanaman Modal dan Pelayanan Terpadu Satu Pintu (BPMPTSP) Privinsi Kalimantan Barat. Vol 1, No 1 Jurnal Manajemen dan Bisnis Universitas. Tanjungpura.

Shimko, Yulniwarti. 2012. Pengaruh gaya Kepemimpinan, Motivasi, dan Lingkungan kerja terhadap Kinerja Pegawai Negeri Sipil pada kantor pemerintahan kabupaten Solok Selatan, Sumatera Barat. Institut Bisnis dan Multimedia asmi.

Shahzadi, Irum, dkk. Impact of Employee Motivation on Employee Performance. The Islamia University of Bahawalpur. Pakistan.

Sedarmayanti. 2011. Manajemen Sumber Daya Manusia, Birokrasi, dan Manajemen Pegawai Negeri Sipil. Bandung: PT. Refika Aditama. 
Sudarmanto. 2009. Kinerja dan Pengembangan Kompetensi SDM. Yogyakarta: Pustaka Pelajar.

Umam, Khaerul. 2010. Perilaku Organisasi. Bandung: Pustaka Setia.

Wibowo. 2014. Manajemen Kinerja. Jakarta: Rajawali Pers.

Wirawan. 2011. Budaya dan iklim organisasi: teori aplikasi dan penelitian. Jakarta: Salemba Empat. 